\title{
Extreme southern locations for moss sporophytes in Antarctica
}

\author{
R.D. SEPPELT', T.G.A. GREEN ${ }^{2}$, A-M. J. SCHWARZ³, and A. FROST4 \\ 'Antarctic Division, Channel Highway, Kingston, Tasmania, 7050, Australia \\ ${ }^{2}$ Biological Sciences, The University of Waikato, Private Bag 3105, Hamilton, New Zealand \\ ${ }^{3}$ DSIR Marine and Freshwater Ecology, Taupo, New Zealand \\ ${ }^{4}$ Montana Vineyards, Blenheim, New Zealand
}

\begin{abstract}
Abundant immature sporophytes of the moss Pottia heimii are reported from the Lower Taylor Valley, McMurdo Dry Valleys and from Cape Chocolate, Victoria Land. These finds extend the reported southern limit for the occurrence of abundant moss sporophytes to $77^{\circ} 55^{\prime} \mathrm{S}$.
\end{abstract}

Received 26 June 1990, accepted 1 May 1991

Key words: bryophyte, McMurdo Dry Valleys, reproduction

\section{Introduction}

Mosses represent a significant component of the terrestrial flora in continental Antarctica. Plants have been reported as far south as $84^{\circ} 42^{\prime} \mathrm{S}$ (Wise \& Gressitt 1965) but there is a sharp decline in species number from around 90 species in the maritime Antarctic, about 12 species at $68^{\circ} \mathrm{S}$ (main Antarctic coastline) to four species in the McMurdo Dry Valleys (Seppelt 1984). There is a similar decline, with increasing latitude, in the reported occurrence of fruiting mosses. Capsules can be commonly found in the Antarctic Peninsula, although reported in less than $25 \%$ of the moss species (Longton 1988) but are much rarer in continental Antarctica. Seppelt (1984) gave only three records from the latter region: Bryum algens $(=B$. pseudotriquetrum) from Fold Island (Filson \& Willis 1975); Pottia heimii from Syowa Station (Nakanishi 1977, Kanda 1981); and Grimmia trichophylla from the Bunger Hills (Australasian Antarctic Expedition 1912). Young, immature sporophytes of Bryum antarcticum (now reidentified as Pottia heimii) had previously been reported once at both Cape Bernacchi $\left(77^{\circ} 28.9^{\prime} \mathrm{S}\right)$ and Marble Point ( $\left.77^{\circ} 25.8^{\prime} \mathrm{S}\right)$ (Greene et al. 1967) (Fig. 1). More recently there have been reports of fruiting in Pottia austrogeorgia, Bryum pseudotriquetrum and Bryum amblyodon from Syowa Station (Kanda 1981), Bryum pseudotriquetrum from the Stillwell Hills, near Fold Island, and from the Vestfold Hills (R.D.S., unpublished data).

Extensive fruiting by several species has been reported
Fig. 1. Known sites for sporophytes in the McMurdo Dry Valleys; open squares, Greene et al. (1967); closed squares, this study. The Granite Harbour site was discovered in 1989 but was not surveyed in detail. Individual sporophytes were better developed than at Canada Glacier.

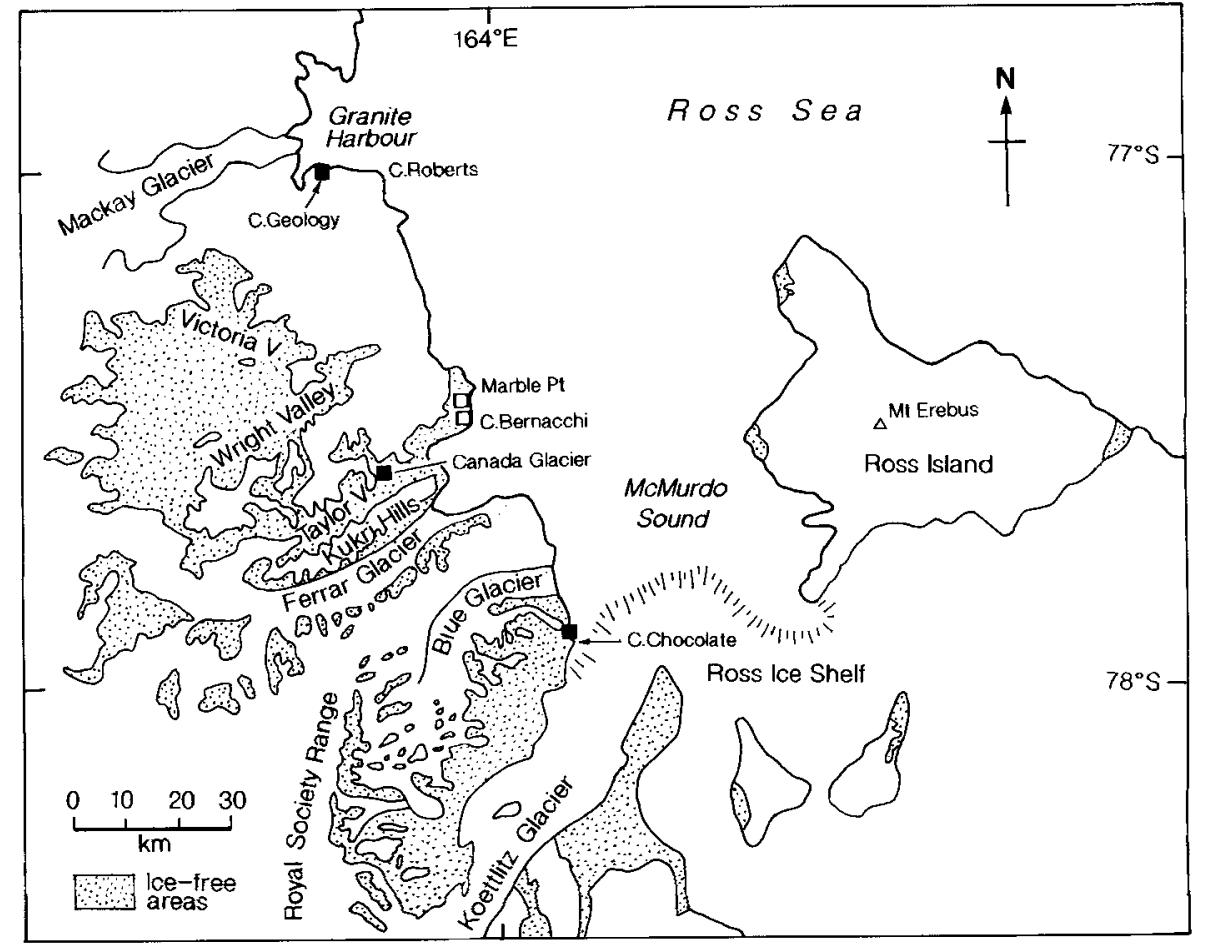




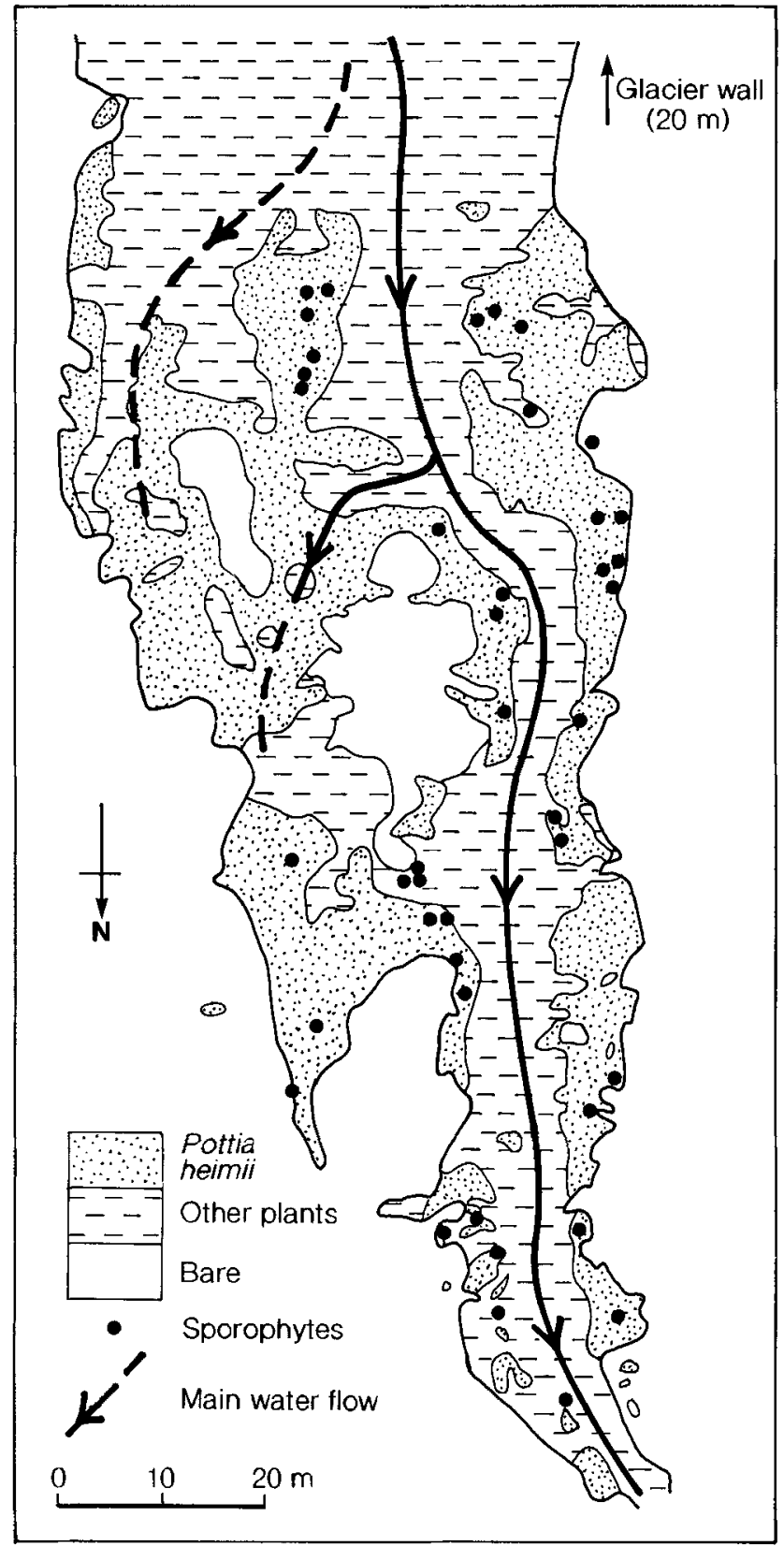

Fig. 2. Bryophyte/algal flush adjacent to Canada Glacier showing the distribution of plants and lines of main water flow. Distribution of Pottia heimii is shown as $>5 \%$ cover. Major algal cover occurs along the lines of main water flow and Bryum argenteum occupies sites between pure algae and $P$. heimii with variable cover of epiphytic algae (mainly cyanobacteria).

from the sheltered Ablation Valley, Alexander Island, $70^{\circ} 45^{\prime} \mathrm{S}$ (Smith 1988) and by Andreaea regularis, Grimmia cf. donniania and Schistidium antarcticum on Thurston Island, $72^{\circ} 30^{\prime} \mathrm{S}$ (R.I.L. Smith, personal communication).

Only two of the records come from areas south of the main Antarctic coastline at around $68^{\circ} \mathrm{S}$ to $72^{\circ} \mathrm{S}$. This paucity may well result from an increase in environmental severity (lower mean summer temperatures, lower free water availability and shorter growing season) with increase in latitude. It must also reflect a lack of suitable growth sites, the North Victoria Land coastline representing one of the few, almost continuous ice-free areas, that reach farther south from $68^{\circ} \mathrm{S}$. We report here the finding of numerous Pottia heimii sporophytes at two locations in the McMurdo Dry Valleys (Fig. 1).

\section{Cape Chocolate/Hobbs Glacier}

This location, visited briefly in December 1976 by a Victoria University expedition, was on the coast between Cape Chocolate and the delta of the Hobbs Glacier melt stream at $77^{\circ} 55^{\prime} \mathrm{S}, 164^{\circ} 32^{\prime} \mathrm{E}$. The fertile mosses, all Pottia heimii, showed relatively luxuriant growth in loose gravel wetted by melt water from Hobbs Glacier. Sporophytes were found at several sites and capsule expansion was noted in some cases with setae up to $8-10 \mathrm{~mm}$ in length. The site is coastal but sea ice is present almost continuously in most years so that maritime influences are not strong. The aspect is predominantly southerly and there is considerable protection from the strong westerly winds by mountains up to $1600 \mathrm{~m}$ high. A west to east ridge over $600 \mathrm{~m}$ high lies to the north and provides protection from cold air flowing down Blue Glacier. These features could be expected to provide a much milder microclimate than at Marble Point and Cape Bernacchi, about $50 \mathrm{~km}$ further north.

\section{Canada Glacier flush}

The flush lies at $77^{\circ} 37^{\prime} \mathrm{S}, 163^{\circ} 33^{\prime} \mathrm{E}$ in the Lower Taylor Valley, and occupies a small area of about $0.5 \mathrm{~h}$ adjacent to the eastern edge of the Canada Glacier. The flush is completely enclosed in SSSI No. 12 which has a management plan that recognizes the importance of this site in the Dry Valleys. The plan is, at present, under review with the aim of extending the boundaries to enclose all vegetation in the Canada Stream catchment. Moss growth appears to have been encouraged by local microclimate at the flush site. The presence of the adjacent, $30 \mathrm{~m}$ ice face of the Canada Glacier to the west protects the flush from both the easterly and westerly winds (up and down the Taylor Valley respectively). The mosses are therefore not subjected to abrasion by windborne dust nor are they blown away in their freeze-dried condition over the winter. The glacier also provides a regular water supply, in December and January, which flows across a gentle slope with little risk of scouring. The flush is believed, from field surveys made in the region, to be the largest, high-density area of moss in the McMurdo Dry Valleys.

Over the 1989/90 Austral summer detailed mapping of the flush was carried out to determine the interactions between the two dominant mosses, Bryum argenteum and $P$. heimii, and the rarer $B$. pseudotriquetrum. A general plan of the flush is shown in Fig. 2.

There is a relatively simple pattern of a central, 
predominantly cyanobacterial zone, dominated by a Nostoc sp. (Broady 1982) along the lines of main water flow, then a $B$. argenteum zone and an outer $P$. heimii zone (Fig. 2). Overall, $B$. argenteum occupies wetter sites and is not found in the drier margins where only salt-encrusted $P$. heimii occurs. Immature sporophytes of $P$. heimii were initially found in the upper, western part of the flush, but, after an exhaustive search, a total of 40 sites were confirmed (Fig. 2). At each site one to several (but less than ten) sporophytes were found, generally 3-6 $\mathrm{mm}$ in length, which were of normal, healthy colour except for occasional white, dead specimens. The capsules had not expanded.

Detailed mapping was carried out to further define the locations in which sporophytes occurred. Two typical microtopographic profiles are given in Figs $3 a$ and $3 b$. These demonstrate that, throughout the flush, sporophytes occurred only in well protected, ephemerally wet, but not saturated, locations. Shelter was the dominant factor since many large areas of $P$. heimii receive adequate water but sporophytes occurred only adjacent to rocks or in hollows. A warmer, more humid environment would be expected at these locations because of the lower wind speed.

\section{Discussion}

These discoveries have extended the southernmost records of sporophyte occurrence to $77^{\circ} 37^{\prime} \mathrm{S}$ and $77^{\circ} 55^{\prime} \mathrm{S}$. The latter is the most southerly fruiting location reported for a moss. The microtopographic studies strongly support the belief that harsh environmental conditions, low temperatures, wind, minimal free water availability, and the short growing season limit sporophyte production. Areas in Antarctica with environmental conditions more favourable to growth have been shown to possess enriched floras, a good example being Ablation Valley, Alexander Island (Smith 1988). A careful search of protected microsites, of the type described here, in moss areas along the Ross Sea coast will probably yield additional records of fruiting mosses, particularly of $P$. heimii.

\section{Acknowledgements}

This work formed part of the 1989 Waikato University, Hamilton, and the 1976 Victoria University, Wellington, Antarctic Research Programmes. Our thanks are given to DSIR, Antarctic Division and to NSF VXE-6 for logistic support. The survey reported here in SSSI No. 12 was authorized by permit from DSIR Antarctic Division, Christchurch.
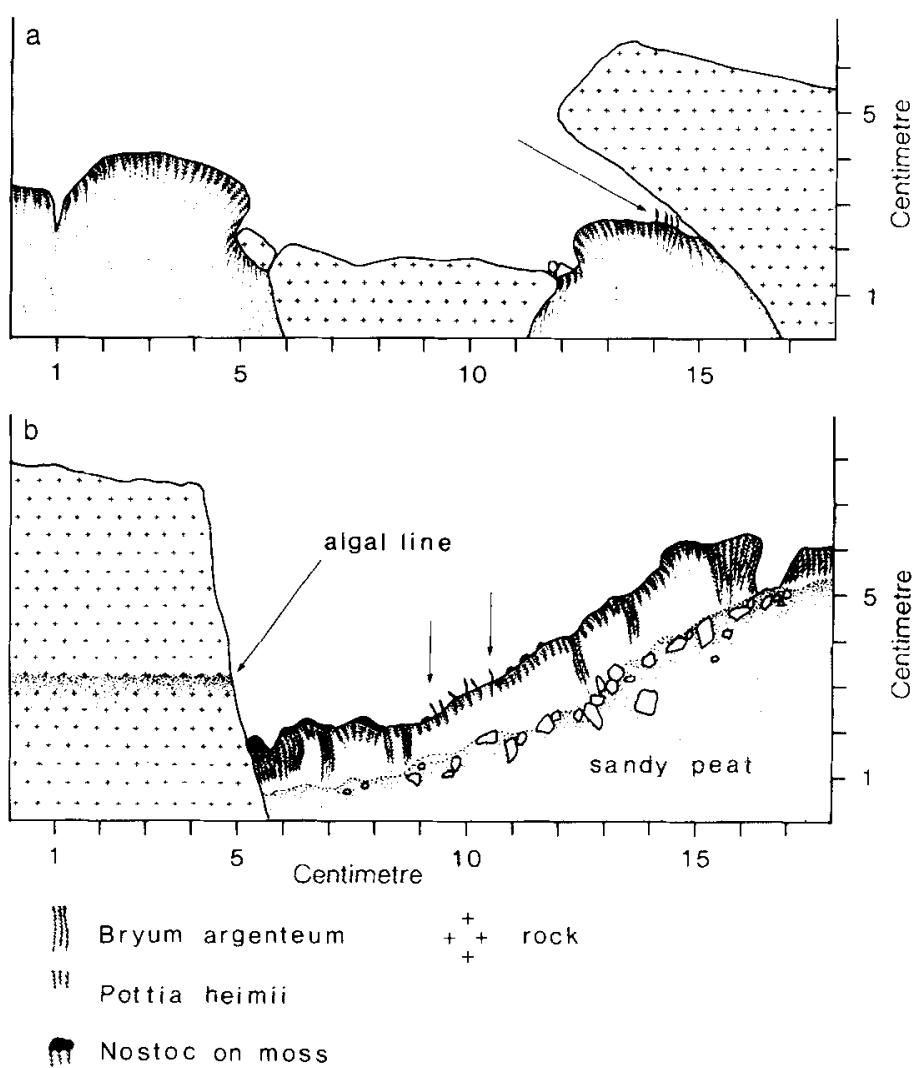

Fig. 3. Microtopographic profiles at two sporophyte locations on the Canada Glacier flush. Positions of sporophytes are indicated by arrows; horizontal and vertical intervals are centimetres. a. extremely protected site under edge of rock; b. sporophytes adjacent to rock face; position of sporophytes approximates the melt water flood level indicated by the clearly marked algal line on rock.

\section{References}

BroAdy, P.A. 1982. Taxonomy and ecology of algae in a freshwater stream in Taylor Valley, Victoria Land, Antarctica. Archiv für Hydrobiologie Supplement No. 3, Algalogical Studies, 32, 331-349.

FiLson, R.B. \& WiLLIS, J.H. 1975. A fruiting occurrence of Bryum algens Card. in East Antarctica. Muelleria, 3, 112-116.

Greene, S.W., Gressitt, J.L., Koö, D., Llano, G.A., Rudolph, E.D., Singer, R., SteERE, W.C. \& Ugolins, F.C. 1967. Terrestrial life of Antarctica. In Bushnell, U.C. ed. Antarctic Map Folio Series, Folio 5. New York: American Geographical Society.

KANDA, H. 1981. Two mosses of the genus Potia collected from the vicinity of Syowa Station, East Antarctica. Antarctic Record, 71, 96-108.

KANDA, H. 1987. Handbook of Antarctic Mosses. Tokyo: National Institute of Polar Research, 83pp. [In Japanese].

LoNGton, R.E. 1988. Biology of polar bryophytes and lichens. Cambridge: Cambridge University Press. 391pp.

NAKANISHI, S. 1977. Ecological studies of the moss and lichen communities in the ice-free areas near Syowa Station, Antarctica. Antarctic Record,59, 68-106.

SEPPELT, R.D. 1984. The bryoflora of the Vestfold Hills and Ingrid Christensen Coast, Antarctica. ANARE Research Notes, 20, 1-31.

Smith, R.I.L. 1988. Bryophyte oases in Ablation Valley on Alexander Island, Antarctica. The Bryologist, 91, 45-50.

WISE, K.A. \& GRESSITT, J.L. 1965. Far southern animals and plants. Nature, 207, 101-102. 